\title{
Characterization of settlement cues used by the rhizocephalan barnacle Loxothylacus texanus
}

\author{
Emily J. Boone ${ }^{1,2, *}$, Anne A. Boettcher ${ }^{1}$, Timothy D. Sherman ${ }^{1}$, Jack J. O'Brien ${ }^{1}$ \\ ${ }^{1}$ Department of Biological Sciences, University of South Alabama, Mobile, Alabama 36688, USA \\ ${ }^{2}$ Present address: Department of Biology, University of Richmond, Richmond, Virginia 23173, USA
}

\begin{abstract}
Populations of the greater blue crab Callinectes sapidus throughout the Gulf of Mexico, as far north as South Carolina, USA, are infected by the rhizocephalan barnacle Loxothylacus texanus. Larvae are non-feeding and have approximately $3 \mathrm{~d}$ from the onset of metamorphosis from their naupliar stage to successfully encounter and recognize a host before their nutrient stores are depleted. The female cypris and kentrogon stages are the initial infective agents. Chemical cues, like those used by free-living barnacles to identify settlement sites, appear to be important in the identification of potential hosts by this parasitic barnacle. The cypris larvae of $L$. texanus settle in response to carbohydrate or glycoprotein cues found in the epicuticle layer of $C$. sapidus exoskeletons. These cues are associated with the epicuticle layer only, not the biofilm associated with the carapace. In fact, the carapace biofilm and lipid-based compounds found in the outer layer of the epicuticle appear to afford crabs some protection against settlement by $L$. texanus.
\end{abstract}

KEY WORDS: Loxothylacus texanus $\cdot$ Settlement $\cdot$ Carbohydrate $\cdot$ Parasite $\cdot$ Callinectes sapidus

\section{INTRODUCTION}

The greater blue crab Callinectes sapidus (Brachyura: Portunidae) is a valuable resource to both recreational and commercial fishermen along the US Gulf Coast and eastern seaboard. Populations of C. sapidus are susceptible to infection by the parasitic rhizocephalan barnacle Loxothylacus texanus (Rhizocephala: Sacculinidae) in the Gulf of Mexico (Christmas 1969, More 1969, Park 1969, Harris \& Ragan 1970, Adkins 1972, Ragan \& Matherne 1974, Hochberg 1988, Wardle \& Tirpak 1991). Although blue crabs can be found in coastal waters along the Atlantic seaboard of North and South America, the parasite is only found on $C$. sapidus and other portunids in the Gulf of Mexico (Alvarez \& Calderon 1996) and the southern Atlantic coast of the US north to South Carolina (Eldridge \& Waltz 1977, as cited in Shields \& Overstreet in press). The parasite may be of potential economic importance for the blue crab fisheries industry in this region where the commercial value of the fishery has been estimated at $\$ 30890000$ (US) annually (Guillory et al. 1998). Infected crabs are indistinguishable from their uninfected

*Email: eboone@richmond.edu counterparts with 3 notable exceptions: (1) Gonads of parasitized crabs do not mature; thus, they do not reproduce (Reinhard 1956). (2) Male crabs are feminized. (3) Parasitized crabs cease to molt at a carapace width below legal size (Reinhard 1950).

Parasitized crabs compete for food and space with unparasitized crabs. Typical recruitment models do not consider the impact of parasitism upon the survival rate of juvenile blue crabs, yet the above 3 factors suggest that the parasite may have a negative economic impact. Understanding how the rhizocephalan detects vulnerable hosts may lead to strategies that decrease the infection rate in the field.

Rhizocephalan barnacles are released from their hosts as lecithotrophic naupliar larvae. After a period of $3 \mathrm{~d}$, these sexually dimorphic nauplii will molt to become cypris larvae. The cyprids have approximately 3 to $4 \mathrm{~d}$ to find a vulnerable host upon which to settle. A female cyprid will settle on a juvenile blue crab and metamorphose on the surface of the crab into a dartlike kentrogon larva (Yanagimachi 1961, Hoeg 1985). After 60 to $70 \mathrm{~h}$, a vermigon larva leaves the kentrogon and enters the host crab (Glenner \& Hoeg 1995, 
Glenner et al. 2000). The vermigon sends out roots that invade host tissues (Hoeg 1990, Glenner et al. 2000). This stage is known as the interna. Callinectes sapidus molts 5 to 9 times during this period of internal development (O'Brien 1999) before undergoing a terminal molt, at which point it acquires the wide abdomen characteristic of the adult female crab. Within a few days of the terminal molt, a virgin externa will emerge from the abdominal cavity of the host crab through the crab cuticle to the exterior. A male cyprid will settle on this virgin externa, metamorphose into a kentrogon larva and inject a trichogon larva into the sac. The external sac grows to become the externa, or adult stage of the barnacle, containing both mature ovaries and testes, from which future broods of naupliar larvae will be released. This cycle will continue as long as appropriate hosts can be located.

Biochemical cues are used by the larvae of many sessile marine invertebrates to successfully identify an appropriate settlement site before mobility is lost (Pawlik 1992). Once released from their crab hosts, the non-feeding larvae of the rhizocephalan, Loxothylacus texanus have only a few days to locate and settle upon an appropriate host before nutrient stores are completely depleted. The window of opportunity for settlement may also be limited in that host vulnerability is thought to be greatest only during the soft-shell state (Glenner \& Werner 1998, O'Brien 1999). Without means for detecting susceptible hosts, successful hostparasite encounters would occur only by chance, a situation not conducive for maintaining the lifecycle of an obligate parasite. There is evidence that crustaceans and parasitic barnacles have interacted as far back as the Mesozoic period (Feldmann 1998).

Cypris settlement of non-parasitic barnacles found on boats and piers has been researched extensively in an effort to find a commercially feasible antifouling compound. Larman et al. (1982) found that glycoproteins extracted from the tissue of adult barnacles Semibalanus balanoides induced settlement of larvae. They concluded that the cue to settle consisted of a polymorphic group of closely related proteins derived from 5000 to 6000 and 18000 dalton molecular weight subunits. The carbohydrate moiety of these glycoproteins was not thought to play an important role in settlement. Balanus amphitrite cyprids respond to a 3000 to 5000 dalton peptide pheromone from adults (Rittschof 1985, Tegtmeyer \& Rittschof 1989). However, Matsumura et al. (1998) reported that a sugar chain that binds to lentil lectin might play an important role in the settlement of $B$. amphitrite.

The exoskeleton of a soft-shell crab is comprised solely of epicuticle and exocuticle and would be the expected location of chemical cues used by the parasite for settlement site location. The outer, epicuticle layer is composed of proteins, carbohydrates, and lipids and is thought to be responsible for restricting the permeability of the cuticle. Although the epicuticle is calcified, chitin, a polysaccharide of the monomer $\mathrm{N}$-acetylglucosamine, has not been found there. In the epicuticle layer, however, a certain degree of variation in proteins among species has been reported (O'Brien et al. 1991). These differences could be used by the parasite to identify the proper species of host.

The objective of this investigation was to characterize the chemical cues Loxothylacus texanus uses to identify its blue crab host, Callinectes sapidus. We first established the duration of competency of cypris larvae and then determined whether or not rhizocephalan barnacles settle on soft-shell carapace in response to biochemical cues present on the carapace.

\section{MATERIALS AND METHODS}

Maintenance of animals. Parasitized crabs were obtained from: Gulf Coast Research Lab, Ocean Springs, Mississippi; Gulf Specimens Marine Lab in Panacea, Florida; Discovery Hall Program, Dauphin Island Sea Lab, Dauphin Island, Alabama. The crabs were maintained in perforated plastic freezer containers in a 4501 recirculating seawater system at the University of South Alabama. Filtered seawater (20 $\mu \mathrm{m}$ pore size) was obtained from the Gulf Breeze Environmental Protection Agency (EPA) lab in Pensacola, Florida. Crabs with externae that were about to release larvae (recognized by their dark brown mantle cavity) were isolated in separate, aerated 191 buckets of filtered seawater (25\%). Under laboratory conditions, releases occurred on a predictable, weekly basis. Each parasitized crab was measured and assigned an identification number to keep track of releases. The larvae, which are non-feeding, were maintained in aerated buckets until the cypris stage was reached (O'Brien 1999).

Uninfected juvenile crabs were obtained using dip nets and seines at Airport Marsh on Dauphin Island and crab traps from Fowl River, Alabama. Two additional tanks (approximately $300 \mathrm{l}$ each) were used to maintain uninfected individuals.

All tanks were maintained at a temperature of $23^{\circ} \mathrm{C}$ and a salinity of $25 \%$. Salinity was checked biweekly and was regulated by the addition of well water as needed. All crabs were fed once daily a diet of beef liver (O'Brien 1999). Tank covers made of black plastic were used to minimize evaporative water loss. Aside from daily feeding, the tanks remained covered at all times.

The molting of individual crabs was induced by squeezing the merus segment (coxa) of each walking leg, causing the crab to reflexively autotomize (drop) 
that limb. Small, autotomized crabs that had 6 walking legs removed would molt within $10 \mathrm{~d}$ (O'Brien 1999). Newly molted crabs were removed from the seawater system and stored at $-20^{\circ} \mathrm{C}$ until needed. Preliminary experiments indicated no significant difference in larval response to frozen carapace as compared to fresh.

Settlement assays. All settlement assays were performed using $11 \mathrm{~cm}$ diameter glass dishes. Soft-shell exoskeletons, or pieces of soft-shell cephalothorax (carapace strips) of equal size from 5 crabs, were added to each dish. Cypris larvae in $200 \mathrm{ml}$ of seawater were placed in each dish. Only cyprids that were within $24 \mathrm{~h}$ post-metamorphosis from the naupliar stage were used. All experiments were carried out using 5 replicates unless otherwise indicated. Each container was covered with aluminum foil to minimize salinity changes due to evaporation. After $3 \mathrm{~d}$, settlement was measured by counting attached cypris and kentrogon larvae. Those larvae that were easily removed with gentle shaking of the tissue were considered unattached. In order to account for the unknown sex ratio of each brood of larvae, all replicates in a given experiment were performed using the same batch of released larvae, with the assumption that ratios remained constant within a single batch. Given the difficulty of distinguishing unsettled female cyprids from their male counterparts, which will not settle, counts were made as a percentage of female kentrogons attached to a given carapace piece compared to the total number of attached female kentrogons on all of the substrates in that dish.

Duration of competency of cypris larvae. The duration of competency of cypris larvae was determined by measuring the changes in metamorphic response as a function of age. Four pieces of soft-shell exocuticle of identical area and stage of ecdysis were placed in separate glass test dishes containing 0 to $12 \mathrm{~h}$ old cypris larvae. Settlement was recorded every $24 \mathrm{~h}$. Each day, for $4 \mathrm{~d}$, an additional set of 4 dishes was prepared using larvae from the same batch that had been maintained in the original, aerated bucket since release. Settlement was recorded in each dish every $24 \mathrm{~h}$ until no new settlement was observed. Experimental data were analyzed using (1) only the first day of settlement for each dish (settlement as a function of cyprid age) and (2) all days of settlement for each set of dishes (settlement as a function of the length of exposure time to the substrate following the onset of metamorphosis).

Tissue preferences. Previous work (O'Brien 1999) indicated that only soft-shell (postmolt) individuals are capable of becoming infected. Our preliminary data suggested, however, that kentrogon formation was possible on hard-shell (intermolt) individuals (pers. obs.). To determine if there was a preference for a particular stage of host ecdysis and to determine if there was any nonspecificity associated with settlement, settlement assays were performed (as described) with the addition of a similar-sized piece of intermolt exoskeleton and similar-sized pieces of Kimwipe ${ }^{\mathrm{TM}}$ paper towels. Kimwipes were chosen for similarity in texture and thickness to the postmolt exoskeleton. Intermolt animals raised in the lab and those that had been frozen directly in the field were used for comparison purposes since it was not known how lab-holding conditions would affect the calcification process. A Ryobi $^{\mathrm{TM}}$ tool with abrasive cutoff disk was used to cut the hard-shell exoskeleton.

To determine whether the larvae were responding to a particular layer of the crab exoskeleton, the exocuticle from a soft-shell crab and the membranous layer dissected from an intermolt crab were divided into equal sections and placed together in test dishes. Each strip was placed dorsal side up. The number of cyprids settled on each strip after $3 \mathrm{~d}$ was recorded, according to the settlement methods described.

A difference in settlement that appeared to be related to a preference for one side of the exoskeletal substrate was observed during initial experiments. To examine this phenomenon, 2 pieces of exoskeleton were placed in a dish external side up or internal side up. The external side was the exoskeleton surface that would normally contact the external environment, whereas the internal side would have faced inward on an intact crab. Two pieces of intermolt carapace were placed in each of the positions along with a Kimwipe.

Initial settlement assays indicated a tendency towards aggregation of settled cyprids on the edges of carapace strips. Additional experiments using whole exoskeleton were performed to determine whether this was a behavioral characteristic or an experimental artifact. Whole pieces of exoskeleton were removed from soft-shell crabs (carapace width 21 to $33 \mathrm{~mm}$ ) and placed dorsal side up in 5 separate glass dishes filled with $200 \mathrm{ml}$ of seawater containing cyprids. Settlement location was recorded after $3 \mathrm{~d}$. Locations were recorded as edge of the carapace $(5 \mathrm{~mm}$ or less from an edge), center of the carapace (area encompassing the points of attachment found on the ventral side of the exoskeleton), or middle of the carapace (all other points of settlement on the carapace).

Influence of bacteria on settlement. Bacterial testing was done in order to determine whether settlement occurred as a result of a cue associated with the carapace of the crab or as a result of the presence of bacteria on the surface of the soft-shell carapace. Soft-shell carapace strips were placed in $6 \mathrm{ml}$ of seawater that had been filtered through a $0.2 \mu \mathrm{m}$ polycarbonate filter. The strips were then sonicated for 1 min using a probe sonicator (60 Sonic Dismembrator, Fisher Scientific) set at $900 \mathrm{~W}$ (McDaniel \& Capone 1985). This pro- 
cess was repeated 3 times with the samples kept on ice to avoid overheating from the sonication process. The samples were placed in microcentrifuge tubes and centrifuged for $10 \mathrm{~min}$ to concentrate the bacteria. The remaining pellets were resuspended in $1 \mathrm{ml}$ of filtered (0.02 $\mu \mathrm{m}$ pore size) deionized water and stained with $\mathrm{STYO}^{\circledR} 9$ green fluorescent nucleic acid stain (Molecular Probes) ( $\left.3 \mu \mathrm{ml}^{-1}\right)$ for $15 \mathrm{~min}$ at room temperature in the dark. Samples were then filtered through $0.2 \mu \mathrm{m}$ black polycarbonate filters. These filters were then placed in $200 \mathrm{ml}$ of filtered seawater for $3 \mathrm{~d}$ to determine whether the bacteria would remain on the filter surface. The presence of bacteria on the filters was confirmed by fluorescent microscopy before and after the assay. Settlement assays were conducted using additional filters, sonicated strips and unsonicated strips, all of which were placed in $200 \mathrm{ml}$ of seawater containing cypris larvae.

Characterization of cues associated with crab soft shell. The exoskeleton of Callinectes sapidus is composed primarily of proteins, lipids, and carbohydrates. Elimination experiments were performed in order to categorize the settlement cue as one of these general components. Exoskeleton strips that had had proteins, lipids or carbohydrates removed were placed together in a test dish along with an untreated postmolt strip (positive control) and a Kimwipe (negative control).

Removal of carbohydrates: Exoskeletons were removed and placed in individual $6 \mathrm{ml}$ plastic vials. Then $4 \mathrm{ml}$ of $10 \mathrm{mM}$ sodium periodate in $50 \mathrm{mM}$ sodium acetate ( $\mathrm{pH} 4.5)$ was added to each vial. The vials were gently shaken in the dark at room temperature for $1 \mathrm{~h}$. Periodate oxidatively cleaves sugar residues producing aldehydes (Hassid \& Abraham 1957). The sodium periodate solution was discarded and the substrates were rinsed 3 times for 5 min each with deionized water. Then $4 \mathrm{ml}$ of $1 \mathrm{M}$ sodium borohydride in Tris buffered saline (TBS: $10 \mathrm{mM}$ Tris $\mathrm{pH} 7.5,150 \mathrm{mM} \mathrm{NaCl}$ ) was added to each vial. This step was necessary to reduce the reactive aldehydes to hydroxyl groups. The vials were shaken gently at room temperature for $1 \mathrm{~h}$. Each strip was rinsed again 3 times for $5 \mathrm{~min}$ each before placement in the test dishes (Kirchman et al. 1982a, Morse \& Morse 1991).

Removal of lipids: Crab exoskeletons were removed and placed in vials with $4 \mathrm{ml}$ of chloroform in each and gently shaken at room temperature for $1 \mathrm{~h}$. All sections were rinsed 3 times for 5 min each with deionized water before being placed in the test dish.

Removal of proteins: Exoskeletons were removed and placed in individual $6 \mathrm{ml}$ vials. Proteinase $\mathrm{K}(5 \mathrm{ml}$, 6 Anson units $\mathrm{ml}^{-1}$ _US Biochemical Cat. No. 20818 in $10 \mathrm{mM}$ Tris $\mathrm{pH}$ 7.8) was added to each container. The vials were slowly mixed by inversion at $37^{\circ} \mathrm{C}$ for $1 \mathrm{~h}$. The Proteinase $\mathrm{K}$ was then discarded and the substrates were rinsed as described for removal of lipids.

Characterization of carbohydrate cue. Initial characterization experiments indicated a carbohydrate component to the settlement cue suggesting that the cypris larvae possess a receptor designed to bind to sugars. Lectins, which are proteins that bind to specific carbohydrates, were used to see if settlement sites on the exoskeleton itself could be blocked, thus hindering cypris receptor binding to the substrate surface. Fluorescent lectins were used to visualize binding of lectins to both periodate-treated and control carapaces.

Lectins: The lectins Concanavalin A (Con A), Lens culinaris (lentil [LCA]), and Triticum vulgaris (wheat germ agglutinate [WGA]) were chosen for testing. Wheat germ agglutinate has an affinity for $\mathrm{N}$-acetyl- $\beta$ D-glucosaminyl residues, whereas Con A and lentil lectin both have affinities for $\alpha$-D-mannosyl and $\alpha$-Dglucosyl residues. Exoskeleton strips, with lipids removed, were placed in a microcentrifuge tube containing $1 \mathrm{ml}$ of a $2 \mathrm{mg} \mathrm{ml}^{-1}$ lectin solution (Kirchman et al. 1982a). The tubes were placed on a rotator for one hour. A set of untreated postmolt carapace strips was also treated with the lectins as described above. All strips then were rinsed 3 times for $5 \mathrm{~min}$. Each of these strips was placed along with a control piece of untreated soft-shell exoskeleton, a piece of hard-shell carapace, and a Kimwipe in $200 \mathrm{ml}$ of seawater containing cyprids.

Fluorescent microscopy of lectin binding: Untreated exoskeleton and exoskeleton from which carbohydrates had been removed were exposed to $0.4 \mathrm{mg} \mathrm{ml}^{-1}$ fluorescent Con A in TBS. The samples were gently agitated for $1 \mathrm{~h}$ and then rinsed 3 times for $10 \mathrm{~min}$ with TBS. Exoskeleton from 5 crabs was divided into strips so that each crab's exoskeleton was exposed to each of the lectin treatments. All samples then were observed under a fluorescence microscope (Olympus B-Max 50 upright fluorescent research microscope with an Optronics cooled CCD camera) to determine if lectin binding had occurred.

Statistical analysis. The number of larvae added to each dish was not estimated. Hence, the response variable for each treatment and replication was the number of kentrogons observed on a given substrate in a dish compared to the total number of kentrogons on all substrates in that dish. For purposes of statistical analyses, the response variable was then expressed as a percentage.

All statistical tests were considered significant at $\mathrm{p}<$ 0.05. Each experiment was analyzed as a Randomized Block Design (Zar 1996). Under this design, the dish was considered the block (random effect) and substrate the main (fixed) effect (Model III). Given that percentages follow a binomial distribution (Sokal \& 
Rohlf 1981), all values of the response variable were arcsin transformed before the ANOVA (Zar 1996). The Tukey multiple comparison test was then performed on all statistically significant ANOVAs (Zar 1996). The family error rate of these comparisons was set at $\mathrm{p}<$ 0.05 , with individual errors dependent on the number of comparisons to be made. Data in the text for each treatment are reported as mean percentage settled $\pm 95 \%$ confidence interval. Confidence intervals were based on the pool error term from the ANOVA.

\section{RESULTS}

\section{Larval competency}

Loxothylacus texanus larvae metamorphosed into cypris larvae after $3 \mathrm{~d}$ from their release as naupliar larvae. As cypris larvae, they are competent to settle and will do so on the first day following metamorphosis when provided with a piece of soft-shell exoskeleton. After becoming cyprids, the duration of competency is approximately $3 \mathrm{~d}$, with the highest rate of settlement occurring on Day 3 (when exposed for $24 \mathrm{~h}$ increments beginning on either Day 1, Day 2, Day 3 or Day 4 following metamorphosis). No further settlement occurs on the fourth day of the cypris stage (Fig. 1A).

Those cyprids that were continuously exposed (24 to $96 \mathrm{~h}$ ) to soft-shell exoskeleton from the onset of metamorphosis (Fig. 1B) had higher rates of settlement on the second day following exposure ( $48 \mathrm{~h}$ of exposure), than on the initial exposure day. Similar results were seen with cyprids that were exposed on the second day following metamorphosis (Fig. 1C). Limited settlement on the fourth day was observed when 2- (Fig. 1C) and 3-d-old cyprids (data not shown) were exposed for 24 to $48 \mathrm{~h}$ to a substrate. No settlement was observed using 4-d-old cyprids (data not shown). As a result of these findings, all subsequent experiments were carried out for an exposure period of $3 \mathrm{~d}$ using cypris larvae $\leq 24 \mathrm{~h}$ post-metamorphosis. The variation in settlement seen in the controls throughout these and subsequent experiments was a result of the variation in settlement among batches. Therefore, all replicates of a given experiment were performed using the same batch of larvae.

\section{General settlement preferences}

The external side of the exoskeleton is the surface that cypris larvae would encounter under natural circumstances. Cyprids exposed to exoskeleton pieces of the carapace that were placed either external or internal side up always chose the external surface (mean settlement number of female kentrogon $=98.2 \pm 5.9$, $\mathrm{n}=5$ ). Likewise, no settlement was recorded on pieces of membranous layer (whereas mean settlement number of female kentrogon on exoskeleton $=1088.8 \pm$ 187.1, $\mathrm{n}=5$ ), an internal portion of the exoskeleton which would not be exposed to the outside environment. The larvae did not settle on the glass bottom of the dish directly beside or beneath the carapace strip, even when the dorsal surface was touching the glass itself. Although no settlement was observed on fieldcollected intermolt carapaces from adult crabs, in
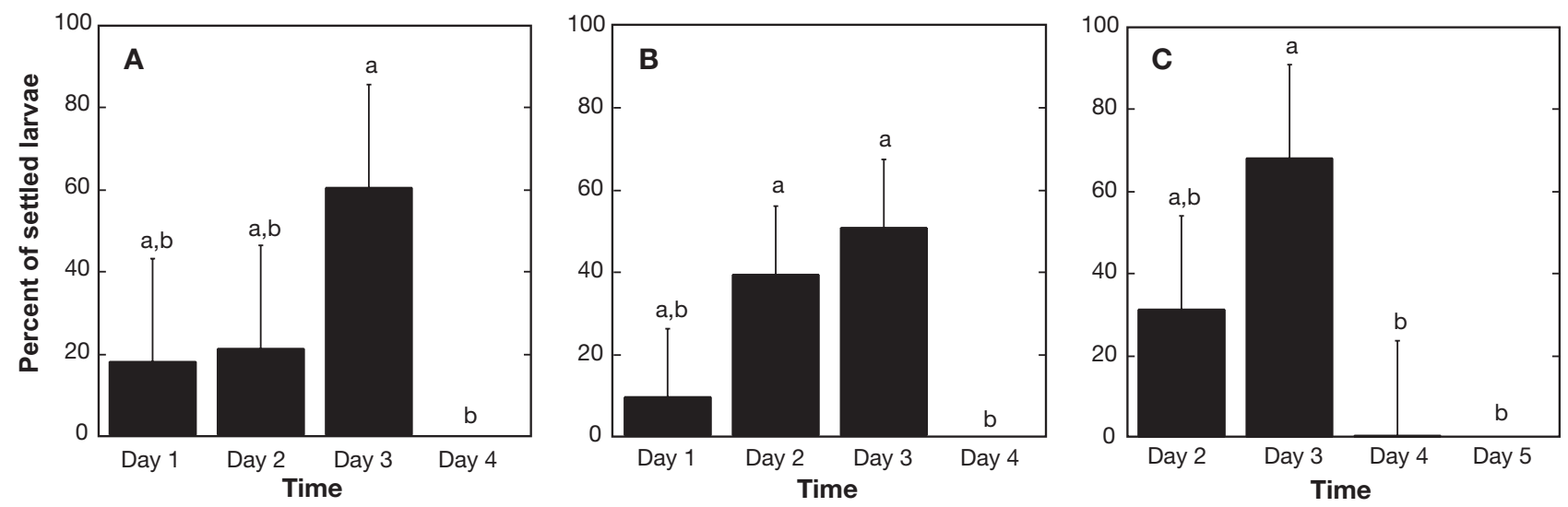

Fig. 1. Loxothylacus texanus. Temporal competency of cypris larvae as measured by mean percentage settlement $\mathrm{d}^{-1}$ (of total settlement in experiment) (A) when exposed to postmolt exoskeleton from Callinectes sapidus on each of $4 \mathrm{~d}$ following metamorphosis (total settlement $=427$ larvae), (B) following prolonged exposure to postmolt exoskeleton from C. sapidus beginning on Day 1 of cypris metamorphosis (total settlement = 709 larvae) and (C) following prolonged exposure to postmolt exoskeleton from C. sapidus beginning on Day 2 of cypris metamorphosis (total settlement $=276$ larvae). Day is defined as the time since metamorphosis to the cypris stage, measured in $24 \mathrm{~h}$ increments. Settlement percentages with the same letters above error bars (within this figure) were not significantly different at $p>0.05(n=4)$. Error bars indicate $95 \%$ confidence intervals 
comparison experiments with intermolt exoskeleton, limited settlement ( $p<0.01$, ANOVA) was observed on field-collected intermolt crabs when used for control purposes in other experiments (see section: 'Lectin observed on laboratory raised intermolt crabs when compared to postmolt individuals. Aggregations of cyprids were observed on the cut ends of carapace strips in some experiments. However, when whole pieces of soft-shell exoskeleton (carapace width 24 to $31 \mathrm{~mm}$ ) were examined for settlement preferences, visual inspection revealed no distinct regions of settlement preference. Alternative substrates such as Kimwipes produced no settlement. Searching behavior, which involves walking across a substrate and touching it with the antennules, was only observed on pieces of exoskeletal tissue, never on a Kimwipe.

\section{Bacterial testing}

Bacteria from the sonication experiment were observed on black polycarbonate filters using a fluorescence microscope indicating that some of the bacteria on the exoskeleton were removed during the sonication process. Follow-up observations of these test filters after placement in seawater showed that the bacteria remained on the filters for at least $3 \mathrm{~d}$. No settlement (Fig. 2) was observed on any bacteria-exposed polycarbonate filters ( $\mathrm{n}=5$ in each of 2 experiments).

Settlement assays showed that sonicated postmolt exoskeleton strips did induce kentrogon formation. In an experiment immediately following sonication, sonicated substrate actually enhanced settlement (91.3 $\pm 3.0 \%$ ) when compared to untreated controls (8.6 \pm binding'). No significant difference in settlement was

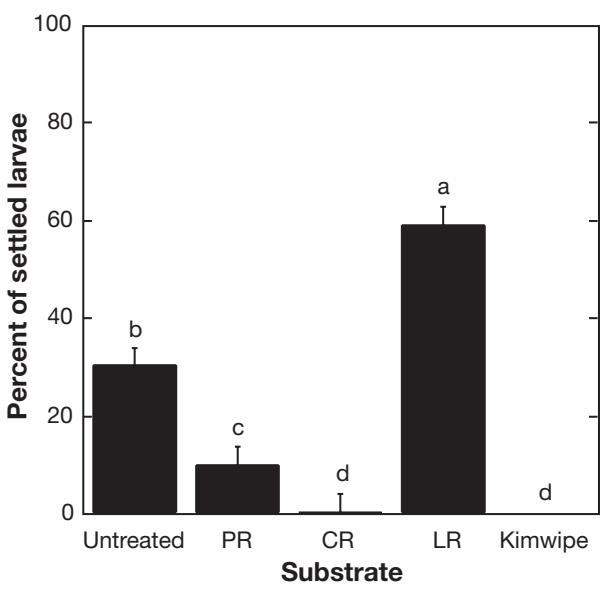

Fig. 3. Loxothylacus texanus. Involvement of chemical cues in larval settlement. Percentage settlement on postmolt exoskeleton following the removal of carbohydrates (CR), lipids (LR) and proteins (PR) as compared to untreated exoskeleton and Kimwipes ${ }^{\mathrm{TM}}$ (total settlement $=3766$ larvae). Settlement percentages with the same letters above error bar (within this figure) were not significantly different at $p>0.05$. Error bars indicate $95 \%$ confidence intervals

$3.0 \%$ ) (Fig. 2A). Such an enhancement was not observed, however with substrate that was frozen at $-20^{\circ} \mathrm{C}$ for $5 \mathrm{~d}$ prior to use (sonicated $54.0 \%$ vs untreated $46.0 \pm 3.0 \%$ ) (Fig. $2 \mathrm{~B})$.

\section{Characterization of cues associated with crab soft shell}

In the elimination experiment, mean kentrogon formation on untreated exoskeleton was $30.3 \pm 3.8 \%$. Removal of proteins resulted in a significant decrease $(\mathrm{p}=0.0033$, Tukey $)$ in settlement rates $(10.1 \pm 3.8 \%)$, as did removal of carbohydrates $(0.4 \pm 3.8 \%)$ compared to untreated exoskeleton ( $\mathrm{p}<0.001$, Tukey). However, removal of lipids enhanced settlement $(59.2 \pm 3.8 \%, \mathrm{p}=$ 0.0026, Tukey) (Fig. 3). Results were consistent with preliminary experiments performed in a no-choice setup where carapace strips (cephalothorax) were exposed individually to cyprids (data not shown).

\section{Lectin binding}

Fig. 2. Loxothylacus texanus. Effect of bacterial removal on cypris larva settlement. Percentage of cypris settled on polycarbonate filters through which sonicated extract was filtered, soft-shelled exoskeleton (sonicated to remove bacteria) and untreated soft-shell exoskeleton. (A) Initial exposure to sonicated exoskeleton occurred immediately following sonication (total settlement = 6386 larvae). (B) All substrates were frozen at $-20^{\circ} \mathrm{C}$ for $5 \mathrm{~d}$ prior to exposure (total settlement $=2640$ larvae) 

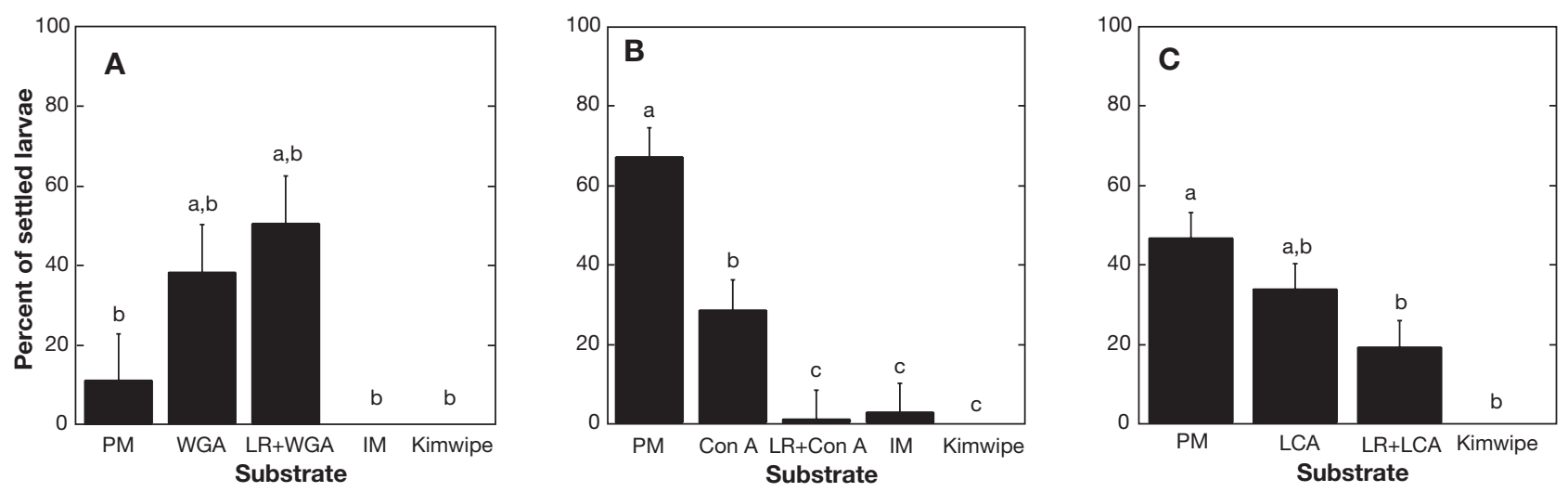

Fig. 4. Loxothylacus texanus. Lectin inhibition of larval settlement assays. (A) WGA binding assay. Percentage settlement of cypris larvae on postmolt exoskeleton (PM), lectin-treated postmolt (WGA), postmolt lectin-treated exoskeleton with lipids removed prior to treatment (LR + WGA), intermolt exoskeleton (IM) and Kimwipe (total settlement = 4007 larvae). (B) Con A binding assay. Percentage settlement of cypris larvae on postmolt exoskeleton (PM), lectin-treated postmolt (Con A), postmolt lectin-treated exoskeleton with lipids removed prior to treatment (LR + Con A), intermolt exoskeleton (IM) and Kimwipe (total settlement $=1985$ larvae). $($ C) LCA binding assay. Postmolt settlement of cypris larvae on postmolt exoskeleton (PM), lectintreated postmolt (LCA), postmolt lectin-treated exoskeleton with lipids removed prior to treatment (LR + LCA) and Kimwipe (total settlement $=2457$ larvae). Settlement percentages with the same letters above error bars (within this figure) were not significantly different at $p>0.05$. Error bars indicate $95 \%$ confidence intervals

Results from WGA alone $(38.4 \pm 11.9 \%)$ were not significantly different from untreated exoskeleton (11.0 \pm $11.9 \%$ ) nor from WGA treatment of lipid-removed strips $(50.6 \pm 1.5 \%)$ (Fig. $4 \mathrm{~A})$. Concanavalin A on the other hand, inhibited settlement on lipid-removed strips $(1.2 \pm 7.4 \%)$ as well as untreated strips exposed to the lectin alone (Fig. 4B). LCA, however, only consistently suppressed settlement on lipid-removed strips (Fig. 4C).

\section{Fluorescent microscopy of lectin binding}

Fluorescent microscopy of carapace strips treated with Con A following the removal of carbohydrates showed little binding of the fluorescent lectin with the substrate (Fig. 5A). These images were compared to exoskeleton strips treated only with Con A, in which a considerable amount of fluorescence was observed (Fig. 5B).

\section{DISCUSSION}

The cypris larvae of Loxothylacus texanus have approximately $3 \mathrm{~d}$ to successfully encounter and recognize an appropriate host before nutrient stores are depleted. In laboratory studies, settlement occurs upon the external exoskeleton but not upon the underlying layer of postmolt exoskeleton removed from Calli-
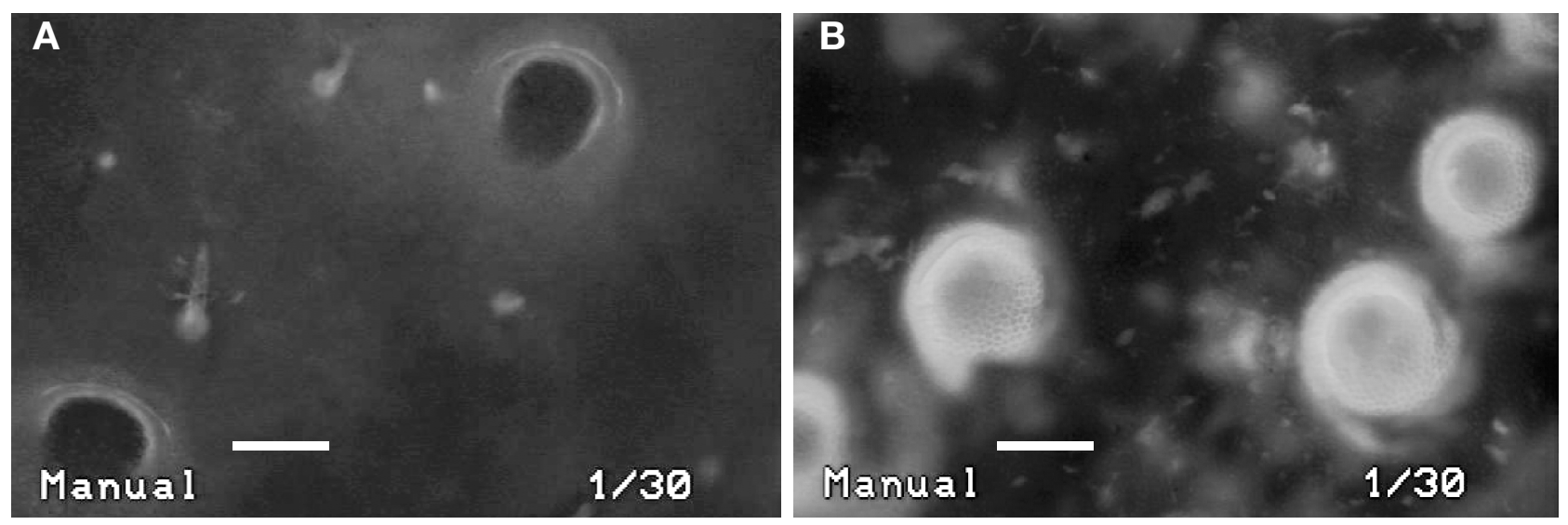

Fig. 5. Callinectes sapidus. Binding of fluorescent lectins to carapace. (A) Postmolt exoskeleton treated with fluorescent Con A following the removal of carbohydrates with sodium periodate/sodium borohydride. (B) Postmolt exoskeleton treated with fluorescent Con A. Areas of fluorescence indicate Con A binding and the presence of mannose and glucose moieties. Scale bar $=50 \mu \mathrm{m}$ 
nectes sapidus. The larvae respond to a carbohydrate cue(s) associated with the epicuticle layer. This response does not appear to be connected with carapace biofilms, and it is enhanced by removal of lipids from the exoskeleton of $C$. sapidus. This suggests that lipids may partially mask the carbohydrate signal. Results from settlement experiments using lentil lectin, concanavalin A, and wheat germ agglutinate indicate that the sugar mannose may be an important component of the signal.

Cypris larvae of thoracian barnacles have been observed to exhibit relaxed substrate specificity as they age, concomitant with consumption of their metabolic energy reserves (Nybakken 2001). The evolutionary or ecological argument is that while some sites are more advantageous than others for a free-living barnacle running out of metabolic reserves, a poor settlement site is better than no site at all. Rhizocephalan barnacles face a different situation because they can only survive if they settle upon a specific host (or a species complex of hosts). Thus, the increased settlement reported here on Day 3 is difficult to explain in the above terms, as the options for parasitic barnacles do not include selecting the most favorable site from a continuum of choices, but that of settling upon a susceptible as opposed to an invulnerable host. It seems more reasonable that the delay observed here may be a result of physiological limitations. The transformations or metamorphoses of a naupliar larva into a cypris larva and, subsequently, into a kentrogon are molts that may require time for developmental changes to occur at cellular, tissue or organ levels within the organism (Høeg 1987, Høeg \& Ritchie 1987).

Detection of the chemical signals under investigation in this study most likely involves the sensory organs on the antennules, as searching behavior of rhizocephalan cypris larvae before settlement involves extensive antennule movement over the substrate surface. During 'walking', the antennules of female Loxothylacus texanus are alternatively swung across the substrate. This activity is markedly different from the swimming motion in which the antennules remain retracted into the anterior mantle cavity (Høeg 1985). The chemosensory properties of antennules of cypris larvae of non-parasitic barnacles were first observed by Nott \& Foster (Nott 1969, Nott \& Foster 1969). The third and fourth antennular segments of male and female rhizocephalan cypris larvae possess setae and expanded plates or aesthetascs. Female cypris larvae lack a prominent 'extra' aesthetasc that can be viewed with light microscopy on the third antennular segment of males (Walker 1985, Glenner et al. 1989). Numerous pores, setae, and sensilla on the attachment organ (third segment), aesthetascs, and carapace have been described (Høeg et al. 1998, Walker 1999) but the roles these structures play in the detection of susceptible hosts remain to be clarified.

In this study, cyprids neither settled on the glass directly adjacent to soft-shell exoskeleton nor did they walk on Kimwipe tissue. These 2 behaviors suggest that settlement cues may have both physical and chemical properties. This specificity extends to the physical and chemical properties of the crab itself, given that there is such a distinct one-sidedness to their ability to settle on exoskeleton. The complete lack of settlement on the internal membranous layer substantiates this argument. Evolutionarily, this type of specificity may minimize premature settlement on an unsuitable substrate such as a dead or partially eaten crab.

Surprisingly, Loxothylacus texanus settled on intermolt exoskeleton. This is contrary to previous work that indicated small (carapace width $<19 \mathrm{~mm}$ ) postmolt, but not intermolt, Callinectes sapidus were vulnerable to infection (O'Brien 1999). Work reported here demonstrates that cypris larvae settlement and subsequent kentrogon formation does occur on laboratory-raised intermolt individuals. Extensive settlement occurred on large intermolt crabs that had been reared in laboratory tanks for 3 mo or more. Such crabs were not only 'bleached', i.e. had lost much of the green pigmentation in the epicuticle typical of the carapaces of field caught crabs, but also appeared to have exoskeletons that were lighter (thinner) than similarly-sized crabs caught in the field. Mineralization of the intermolt cuticle requires copious amounts of calcium, usually $\mathrm{CaCO}_{3}$ in solution in the seawater (Richards 1951), and it is possible that the calcium concentrations in the maintenance tanks were less than that in local bays and estuaries. Only a few kentrogons were observed to have formed on intermolt exoskeleton taken from field-caught crabs (Fig. 4B). These findings suggest that the physical condition of the crab as well as that of the environment plays a role in determining the degree of vulnerability to infection (Ritchie \& Høeg 1981). While settlement may occur in the field on intermolt individuals, infection may not be possible because the stylet of the kentrogon cannot penetrate the hard, thick intermolt cuticle. Thinner carapaces of small, juvenile crabs may lack the necessary degree of mineralization that would prevent penetration and subsequent infection.

Juvenile crabs may also be at a disadvantage due to their frequent molting. Certainly it is likely that the thin postmolt exoskeleton, before the endocuticle and membranous layer are synthesized, would be easier to penetrate than the thick cuticle of an individual in intermolt. Frequent molting also means that the biological film (composed of surface bacteria, protozoans, and other epibionts present on intermolt crab exo- 
skeleton) does not have as much time to develop as on larger crabs. Younger crabs and newly molted individuals may lack the high bacteria count present on the exoskeleton of larger, intermolt crabs. While many species of marine invertebrates rely on bacterial films to induce settlement and metamorphosis (Kirchman et al. 1982b, Letourneux \& Bourget 1988, Weiner et al. 1989, Rodriguez \& Epifaunio 2000), this does not appear to be true for Loxothylacus texanus (Fig. 2). On the contrary, settlement assays performed on postmolt exoskeleton strips sonicated to remove bacteria, showed an increase in kentrogon formation compared to untreated postmolt exoskeleton (Fig. 2A). In this species, bacteria might serve as a protective barrier, covering cues used by outside invaders, or sonication may have removed some unknown factor masking the settlement cue.

The epicuticle is composed mainly of proteins, lipids, carbohydrates, and calcium. It is relatively impermeable and is thought to protect against penetration of the cuticle by microorganisms (Soderhall \& Unestam 1975). The epicuticle of the exterior exoskeleton is composed of 2 main layers, an outer layer containing lipids and an inner layer containing mainly protein (Richards 1951, Neville 1975). Removal of lipids during the chemical cue experiments showed enhanced settlement compared to controls (Fig. 3). Thus, it would seem likely that the chemical cue lies in the second, inner layer of the epicuticle, which ordinarily is somewhat concealed by an outer lipid layer. More permeable areas of the crab (such as the intersegmental membranes at the joints) might, therefore, be more attractive to the cyprids than the carapace surface.

The cue itself appears to be a carbohydrate or protein-carbohydrate complex. Elimination experiments showed that although the removal of carbohydrates and proteins suppressed settlement, the removal of carbohydrates decreased settlement to a much greater extent than that of protein removal (Fig. 3). Multi-cue settlement responses have been noted in larval species (Rodriguez \& Epifanio 2000). Data reported here suggest that for Loxothylacus texanus a portion of the cue is carbohydrate or protein-carbohydrate based. Other cues may be involved as well.

Lectins, proteins that bind to specific carbohydrates (Goldstein \& Hayes 1978), have been found to play a key role in the settlement and metamorphosis of several taxonomically diverse marine invertebrates (Kirchman et al. 1982a, Maki \& Mitchell 1985, Bahamondes-Rojas \& Dherbomez 1990, Bonar et al. 1990, Morse \& Morse 1991, Krug \& Manzi 1999). Sessile barnacle larval metamorphosis in response to glycoproteins was shown to be abolished when the oligosaccharide chains of the proteins were exposed to lectins. This was interpreted as meaning that the signal mole- cules were carbohydrates and were, therefore, inaccessible to larval receptors (Matsumura et al. 1998). Specifically, results from lectin work on free-living barnacles indicated that LCA binds to the sugar chain of the settlement-induced glycoprotein involved in the settlement of Balanus amphitrite (Matsumura et al. 1998). These investigators found that both LCA and Con A inhibited adult extract-induced settlement. WGA and peanut agglutinate (PNA) did not have any affect on settlement.

The results of the lectin studies support the role of carbohydrates in Loxothylacus texanus settlement. Both Con A and LCA suppressed settlement when lipids had been removed prior to lectin incubation. While Con A reduced kentrogon formation without the removal of lipids, LCA did not do so consistently (Fig. 4C). Con A and LCA both have affinities for $\alpha$-Dmannosyl and $\alpha$-D-glucosyl residues, but it appears that LCA may be less effective at binding to and masking the signal. The data for wheat germ agglutinate however, which has an affinity for $\mathrm{N}$-acetyl- $\beta$-Dglucosaminyl residues, indicates an enhancement of settlement following exposure to this lectin (Fig. 4A).

Fluorescent micrographs taken of carapace treated with Con A following carbohydrate removal support the settlement data (Fig. 5). Decreased fluorescence was observed with Con A, suggesting that the carbohydrate removal process, which inhibits settlement, also removed the terminal sugar chain that binds to Con A. The combined evidence strongly indicates a cue that is composed of a carbohydrate or glycoprotein with mannosyl or glucosyl residues. Direct confirmation of this cue would involve isolation of a specific oligosaccharide that is able to induce settlement. Low molecular weight sugars can inhibit lectin-mediated processes since the sugar competes for the carbohydrate binding site on the protein (Sharon \& Lis 1972). Preliminary experiments to block settlement using sugars, including mannose, appear to confirm this; however, further experiments are needed.

The controlled environment used in this study allowed for the examination of specific settlement cues of cypris larvae in close proximity to the experimental substrates. Under natural conditions, however, it is likely that a sequence of cues of varying intensities and properties enable animals to successfully locate potential hosts. It seems reasonable to assume, for example, that a chemical (or chemicals) in fluids released into the water column from a molting crab might stimulate a swimming cyprid to undergo circular swimming or 'searching' behavior until coming into contact with postmolt exoskeleton. Such cues could be different from those on the surface of the exoskeleton that would initiate metamorphosis into the kentrogon larva. 
Acknowledgements. The authors thank Dr. R. Overstreet and J. Streckler of the Gulf Coast Research Lab and The Discovery Hall Program, Dauphin Island Sea Lab for parasitized crabs, the Gulf Breeze Environmental Protection Agency Lab for seawater, Dr. T. Shafer, University of North Carolina, Wilmington for advice on lectins, Dr. R. Kiene, University of South Alabama and Dauphin Island Sea Lab for suggestions regarding the bacterial sonication experiment, Dr. J. McCreadie, University of South Alabama for statistical assistance, and numerous individuals for assistance in collection of non-parasitized crabs. Partial funding for this project was provided by the Barber Fellowship, Department of Marine Sciences, University of South Alabama (to E.J.B.).

\section{LITERATURE CITED}

Adkins G (1972) Notes on the occurrence and distribution of the rhizocephalan parasite (Loxothylacus texanus Boschma) of blue crabs (Callinectes sapidus Rathbun) in Louisiana estuaries. La Wildl Fish Comm Tech Bull 2:1-13

Alvarez F, Calderon J (1996) Distribution of Loxothylacus texanus (Cirripedia: Rhizocephala) parasitizing crabs of the genus Callinectes in the Southwestern Gulf of Mexico. Gulf Res Rep 9:205-210

Bahamondes-Rojas I, Dherbomez M (1990) Purification partielle de substances glyconjuguées capables d'induire la metamorphose des larves competentes d'Eubranchus doriae (Trinchese, 1879), mollusque nudibranche. J Exp Mar Biol Ecol 144:17-27

Bonar DB, Coon SL, Walch M, Weiner RM, Fitt W (1990) Control of oyster settlement and metamorphosis by endogenous and exogenous chemical cues. Bull Mar Sci 46: 484-498

Christmas JY (1969) Parasitic barnacles in Mississippi estuaries with special reference to Loxothylacus texanus Boschma in the blue crab (Callinectes sapidus). In: Web JW (ed) Proc 22nd Annu Conf Southeast Assoc Game Fish Comm, October 21-23, 1968, Baltimore, MD. Southeastern Association of Game and Fish Commissioners, Columbia, SC, p 272-275

Eldridge PJ, Waltz W (1977) Observations of the commercial fishery for blue crabs Callinectes sapidus in estuaries in the southern half of South Carolina. Technical Report SCMR 21, 5. South Carolina Wildlife and Marine Resources Dept, Columbia, SC

Feldmann RM (1998) Parasitic castration of the crab, Tumidocatinus giganteus Glaessner, from the Miocene of New Zealand: Coevolution within the Crustacea. J Paleontol 72(3):493-498

Glenner H, Werner M (1998) Increased susceptibility of recently molted Carcinus maenus (L.) to attach by the parasitic barnacle Sacculina carcini. J Exp Mar Biol Ecol 228: 29-33

Glenner H, Høeg JT, Klysner A, Brodin Larson B (1989) Cypris ultrastructure, metamorphosis and sex in seven families of parasitic barnacles (Crustacea: Cirripedia: Rhizocephala). Acta Zool 70:229-242

Goldstein IJ, Hayes CE (1978) The lectins: Carbohydrate binding proteins of plants and animals. Adv Carbohydr Chem Biochem 35:127-334

Guillory V, Perry HM, Steele P, Wagner T, Hammerschmidt P, Heath S, Moss C (1998) The Gulf of Mexico blue crab fishery: Historical trends, status, management and recommendations. J Shellfish Res 17:395-403

Harris AH, Ragan JG (1970) Observations on the ecology and incidence of Loxothylacus texanus (Boschma) parasitic in the blue crab (Callinectes sapidus Rathbun) in south Louisiana. Proc SW Assoc Parasit (Abstract)

Hassid WZ, Abraham S (1957) Chemical procedures for analysis of polysaccharides. Methods Enzymol 3:34-50

Hochberg RJ (1988) Aspects of the ecology and life history of, and host modification in, the parasite/host relationship of Loxothylacus texanus to Callinectes sapidus along the west coast of Florida. MS thesis, University S Florida, Tampa, FL

Høeg JT (1985) Cypris settlement, kentrogon formation and host invasion in the parasitic barnacle Lernaeodiscus porcellanae (Muller) (Crustacea: Cirripedia: Rhizocephala). Acta Zool 66(1):1-45

Høeg JT (1987) The relation between cypris ultrastructure and metamorphosis in male and female Sacculina carcini (Crustacea: Cirripedia). Zoomorphology 107:299-311

Høeg JT, Ritchie LE (1987) Correlation between cypris age, settlement rate and anatomical development in Lernaeodiscus porcellanae (Cirripedia: Rhizocephala). J Mar Biol Assoc UK 67:65-75

Høeg JT, Hosfeld B, Jensen PG (1998) TEM studies of lattice organs of cirripede cypris larvae (Crustacea: Thecostraca: Cirripedia). Zoomorphology 118:195-205

Kirchman D, Graham S, Reish D, Mitchell R (1982a) Lectins may mediate in the settlement and metamorphosis of Janua (Dexiospira) brasiliensis grube (Polychaeta: Spirorbidae). Mar Biol Lett 3:131-142

Kirchman D, Graham S, Reishi D, Mitchell R (1982b) Bacteria induce settlement and metamorphosis of Janua (Dexiospira) brasiliensis grube (Polychaeta: Spirorbidae). J Exp Mar Biol Ecol 56:153-163

Krug PJ, Manzi AE (1999) Waterborne and surface-associated carbohydrates as settlement cues for larvae of the specialist marine herbivore Alderia modesta. Biol Bull 197: 94-103

Larman NV, Gabbot PA, East J (1982) Physico-chemical properties of the settlement of the barnacle Balanus balanoides. Comp Biochem Physiol 72B:329-338

LeTourneaux F, Bourget E (1988) Importance of physical and biological settlement cues used at different spatial scales by the larvae of Semibalanus balanoides. Mar Biol 97: $57-66$

Maki JS, Mitchell R (1985) Involvement of lectins in the settlement and metamorphosis of marine invertebrate larvae. Bull Mar Sci 37:675-683

Matsumura K, Mori S, Nagano M, Fusetani N (1998) Lentil lectin inhibits adult extract-induced settlement of the barnacle, Balanus amphitrite. J Exp Zool 280:213-219

McDaniel JA, Capone DG (1985) A comparison of procedures for the separation of aquatic bacteria from sediments for subsequent direct enumeration. J Microbiol Methods 3: 291-302

More WR (1969) A contribution to the biology of the blue crab (Callinectes sapidus Rathbun) in Texas, with a description of the fishery. Texas, Parks \& Wildlife Dept, Technical Series 1:1-31

Morse D, Morse A (1991) Enzymatic characterization of the morphogen recognized by Agaricia humilis (Sceleratin Coral) larvae. Biol Bull 181:104-122

Neville AC (1975) Biology of the arthropod cuticle. SpringerVerlag, Berlin

Nott J (1969) Settlement of barnacle larvae: Surface structure of the antennular attachment disc by scanning electron microscopy. Mar Biol 2:248-251

Nott J, Foster B (1969) On the structure of the antennular attachment organ of the cypris larva of Balanus balanoides (L.). Phil Trans R Soc B 256:115-134 
Nybakken JW (2001) Marine biology: an ecological approach. Addison Wesley Longman, San Francisco

O'Brien JJ (1999) Limb autonomy as an investigatory tool: Host molt-stage affects the success rate of infective larvae of a rhizocephalan barnacle. Am Zool 39:580-588

O'Brien JJ, Kumari SS, Skinner D (1991) Proteins of crustacean exoskeletons: I. Similarities and differences among proteins of the four exoskeletal layers of four brachyurans. Biol Bull 181:427-441

Park JR (1969) A preliminary study of portunid crabs in Biscayne Bay. Q J Fla Acad Sci 32:12-20

Pawlik JR (1992) Induction of marine invertebrate larval settlement: evidence for chemical cues. In: Paul VJ (ed) Ecological roles of marine natural products. Cornell University Press, Ithaca, p 189-236

Ragan JG, Matherne BA (1974) Studies on Loxothylacus texanus. In: Amborski RL, Hood MA, Miller RR (eds) Proc Gulf Coast Reg Symp Dis Aquat Anim, August 16-17, 1974, Louisiana. Louisiana State University Sea Grant, Baton Rouge, LA, p 185-203

Reinhard EG (1956) Parasitic castration of Crustacea. Exp Parasitol 5:79-107

Reinhard EG (1950) An analysis of the effects of a sacculinid on the external morphology of Callinectes sapidus Rathbun. Biol Bull 98:277-288

Richards AG (1951) The integument of arthropods. University of Minnesota Press, Minneapolis

Ritchie LE, Høeg JT (1981) The life history of Lernaeodiscus porcellanae (Cirripedia Rhizocephala) and co-evolution with its porcellanid host. J Crustac Biol 1:334-347

Rittschof D (1985) Oyster drills and the frontiers of chemical ecology: Unsettling ideas. Am Malacol Bull Spec Edn 1: 111-116

Rodriguez RA, Epifanio CE (2000) Multiple cues for induction of metamorphosis in larvae of the common mud crab Panopeus herbstii. Mar Ecol Prog Ser 195:221-229

Editorial responsibility: Joseph Pawlik (Contributing Editor), Wilmington, North Carolina, USA
Sharon N, Lis H (1972) Lectins: Cell-agglutinating and sugarspecific proteins. Science 177:949-959

Shields JD, Overstreet RM (in press) Diseases, parasites and other symbionts, Chap 8. In: Kennedy VS, Cronin LE (eds) The blue crab, Callinectes sapidus. Maryland Sea Grant, University Maryland System, College Park, MD

Soderhall K, Unestam T (1975) Properties of extracellular enzymes from Aphanomyces astaci and their relevance in the penetration process of crayfish cuticle. Physiol Plant 35:40-46

Sokal RR, Rohlf FJ (1981) Biometry, 2nd edn. WH Freeman, San Francisco

Tegtmeyer K, Rittschof D (1989) Synthetic peptide analogs to barnacle settlement pheromone. Peptides 9: 1403-1406

Walker G (1985) The cypris larvae of Sacculina carcini Thompson (Crustacea: Cirripedia: Rhizocephala). J Exp Mar Biol Ecol 93:131-145

Walker G (1999) The cypris larvae of the rhizocephalan barnacle, Heterosaccus lunatus with particular reference to antennular morphology. Acta Zool 80:209-217

Wardle WJ, Tirpak AJ (1991) Occurrence and distribution of an outbreak infection of Loxothylacus texanus (Rhizocephala) in blue crabs of Galveston Bay, Texas, with special reference to size and coloration of the parasite's external reproductive structures. J Crustac Biol 11: $553-560$

Weiner RM, Walch M, Labare M, Bonar DB, Colwell RR (1989) Effects of biofilms of the marine bacterium Alteromonas colwelliana (LST) on the set of the oysters Crassosterea gigas (Thunberg, 1793) and C. virginica (Gmelin, 1791). J Shellfish Res 8:117-123

Yanagimachi R (1961) The life-cycle of Peltogasterella (Cirripedia, Rhizocephala). Crustaceana 2:183-186

Zar JH (1996) Biostatistical analysis, 3rd edn. Prentice Hall, Englewood Cliffs, NJ

Submitted: February 8, 2002; Accepted: September 5, 2002 Proofs received from author(s): April 15, 2003 